CS A. Grønn \& I. Marijanovic (eds.) Russian in Contrast, Oslo Studies in Language 2(1), 2010. 181210. (ISSN 1890-9639)

http://www.journals.uio.no/osla

\title{
SUBJUNCTIVE IN RUSSIAN RELATIVE CLAUSES
}

\author{
NINA DOBRUSHINA \\ State University, Higher School of Economics, Moscow
}

\section{ABSTRACT}

The paper aims at determining the factors that trigger the choice of subjunctive in relative clauses, where it freely alternates with indicative forms. The factors are established on a basis of frequency of occurrence in Russian National Corpus (www.ruscorpora.ru) and include the referential status of the noun heading the relative clause, polarity, semantic type and epistemic status of the main predicate and the affirmative vs. interrogative status of the whole sentence.

\section{[1] INTRODUCTION}

The Russian subjunctive is an irrealis mood. Crosslinguistically, irrealis mood is often used in the dependent clauses. The use of irrealis is best described in conditional clauses and certain types of complement clauses. Its use in relative clauses, on the other hand, is hardly mentioned in typological studies such as (Elliott 2000) and (Palmer 2001). The discussion is usually limited to Romance languages, since the use of subjunctive in relative clauses is widespread and often obligatory in these languages (Kampers-Mahne 1991; Givón 1994; Panzeri 2004). The subjunctive in Russian relative clauses has only recently become a topic of investigation (Kagan 2007; Borshchev et al. 2007; Nikunlassi 2008; Dobrushina 2009); but the topic is not discussed in e.g. Švedova et al. (1980a,b); Bondarko et al. (1990), certainly because the use of the subjunctive is optional, and most often may be substituted by the indicative.

(1) Надо разработать такую социальную систему, которая максимально защищала бы [ $\checkmark$ защитит] детей из малообеспеченных семей.

'We should create a social infrastructure that would protect children coming from families with low income'.

[Ирина Мельникова. Школа выживания (2003) // «Итоги», 2003.02.11]

This paper will study the conditions under which the usage of the subjunctive in Russian relative clauses becomes possible. Some French examples will be given in order to show that the choice of the mood form is language-specific and to provide a contrastive background to the Russian data. 
The structure of the present article is as follows. Section [1.1] provides a classification of relative clauses based on their (ir)reality. In Section [2], the usage of the subjunctive in 'real' relative clauses is discussed. Section [3] considers hypothetical relative clauses and investigates the conditions under which the usage of the subjunctive becomes possible. Section [4] considers the usage of the subjunctive in counterfactual relative clauses. Section [5] is a summary of the analysis.

\section{[1.1] Real, hypothetical, counterfactual}

The main parameter responsible for the choice between subjunctive vs. indicative is whether the event has taken place or not. Based on this semantic component, I will divide relative clauses into three types: real, hypothetical, and counterfactual. I will refer to the relative clause as REAL if the situation referred to has taken place. This type of relative clause is usually marked by the indicative and thus remains beyond the scope of the present study:

(2) Похоже, ничего уже не изменится в ситуации, которую создали [*создали бы] железнодорожники для новороссийских пассажиров.

'It looks like nothing is going to change in the situation which was created for the railway passengers in Novorossijsk by the railroad employees'.

[Елена Калашникова. Реформа, как беда, не приходит одна (2003) // «Новороссийский рабочий», 2003.01.16]

$\Rightarrow$ It is true that железнодородники создали определенную ситуацию.

However, even this semantic type of relative clauses can contain the subjunctive. Such cases will be discussed in Section [2].

HYPOTHETICAL clauses denote events which can be judged neither as real nor as counterfactual. Such clauses can use either the subjunctive or indicative. The choice of the verb form depends on many factors which will be discussed in Section [3]. Here is an example:

(3) Надо разработать такую социальную систему, которая максимально защищала бы $[\checkmark$ защитит] детей из малообеспеченных семей.

'We should create a social infrastructure that would protect children coming from families with low income.'

$\Rightarrow$ It may be false or true that социальная система защитит детей.

In this situation, French also allows alternation between the subjunctive and indicative:

(4) Il faut mettre au point un système qui protège (SUBJ) [ $\checkmark$ protégera (FUT)] les enfants de familles pauvres.

'We should create a social infrastructure that would protect children coming from families with low income.' 
COUNTERFACTUAL relative clauses denote situations which have not taken place and will never take place. This type of relative clauses has obligatory subjunctive marking both in Russian and French.

(5) Вот вам 32 миллиона электората, которые могли бы быть наши.

'Here you go, 32 million electors that could have belonged to us.'

[Заседание клуба «Новые правые» (2004)]

$\Rightarrow$ It is false that 32 миллиона электората принадлежат нам.

\section{[1.2] Data}

The Russian examples come from the Russian National corpus. The French examples are elicited, and I would like to thank Gilles Authier and Denis Creissels for their generous help.

\section{[2] SUBJUNCTIVE IN REAL RELATIVE CLAUSES}

One could expect the subjunctive never to mark predicates referring to real situations. There is however a special type of the subjunctive usage which occurs in real relative clauses as well as in other indicative contexts. The subjunctive particle $\sigma b$ can be used pragmatically, most often in combination with the 1st person subject, to increase the politeness of the construction. The subjunctive in relative clauses of this type does not signal that the proposition is false (as counterfactual clauses do), nor is it indeterminate with respect to the truth value (like hypothetical relative clauses). These relative clauses unambiguously denote real situations. Subjunctive contexts of this type are often performative (they are considered among other means of expressing performative speech acts in (Apresyan 1995, 203).

(6) Я бы хотел так: печатный лист материала -50 руб., лист своего текста -100 руб., получать же плату помесячно - 100 руб., кроме первого, 8 котором я попросил бы Вас дать мне 200 руб., ибо полагаю прикупить себе книжек.

'I suggest the following: one quire of these materials is 50 roubles, and one quire of my own text is 100 roubles, and I will get a monthly fee of 100 roubles, but not the first month, for which I would like to ask 200 roubles, because I want to buy some books.'

[П. С. Сухотин. Письма к К. Ф. Некрасову (1913)]

$\Rightarrow$ It is true that $я$ хочу так....

$\Rightarrow$ It is true that в первом месяце я прошу вас дать мне 200 рублей.

This usage is most frequent under the verbs xomemb and xomembcr, typically with $1^{\text {st }}$ person reference. 
(7) Есть ещё две темы, которые я хотел бы [ $\checkmark$ хочу] осветить. Это Ирак и Северная Корея.

'There are two more topics that I would like to cover: Iraq and North Korea'.

[А. Климов, В. Лукин. Беседа А. Климова с В. Лукиным в эфире радиостанции «Эхо Москвы» (2003)]

(8) Теперь мы с уверенностью предлагаем его производителям ноутбуков, которые хотели бы [ $\checkmark$ хотят] создавать эффективные с точки зрения энергопотребления продукты.

'Now, we may safely suggest it to the laptop manufacturers, who would like to produce items that would be efficient in terms of power saving'.

[Вячеслав Соболев. Есть ли шансы у XGI // «Computerworld», 29, 2004]

$\Rightarrow$ It is true that производители ноутбуков хотят создавать эффективные ... продукты.

Relative clauses with the pragmatic $6 u$ may refer to definite NPs and may be nonrestrictive:

(9) Тогда я позвонила своему дорогому Пласидо в Испанию, человеку очень богатому, который, я знала, хотел бы $[\checkmark$ хочет] попробовать вложить деньги в скрипки.

'And then I called Spain, I called my dear Placido, a man who is very wealthy and who I knew was interested in investing in the violin.'

[Сати Спивакова. Не всё (2002)]

[3] SUBJUNCTIVE IN HYPOTHETICAL RELATIVE CLAUSES

In this section, I consider a class of subjunctive relative clauses which have two properties in common:

- the subjunctive is optional in the sense that it can be replaced by the indicative (more or less felicitously)

- the truth value of the situation denoted by the relative clause cannot be established

The usage of the subjunctive in hypothetical relative clauses is described in terms of tendencies rather than strict rules. There are several factors that make the usage of the subjunctive possible in hypothetical relative clauses:

(a) the polarity of the main predicate

(b) the semantic type of the main predicate

(c) the referential status of the head noun of the relative clause 
(d) the epistemic status of the main predicate

(e) the affirmative vs. interrogative status of the whole sentence

[3.1] Subjunctive clauses under negative polarity

About $30 \%$ of the subjunctive relative clauses in the Corpus are triggered by a main clause containing a negative predicate.

(10) У насс техникой безопасности всегда были особые отношения: не было такого правила, которое бы не нарушалось [ $\checkmark$ не нарушалось], не было такого запрета, на который бы не плевали [ $\checkmark$ не плевали] ...

'We have always been very consentious about the safety arrangements. There was not a single rule that would not be broken, not a single prohibition that would not be carelessly discarded.'

[Мальчик у шахты тихо играл (2003)// «Криминальная хроника», 2003]

(11) Но никому не удавалось сочинить такую карту, для которой не хватало бы $[\checkmark$ не хватает $]$ четырёх красок.

'But no one was able to invent a map for which four colors would not be enough.'

[В. А. Успенский. Витгенштейн и основания математики (2002)]

(12) Самое главное / что там не видно силы / которая это могла бы остановить [ $\checkmark$ может остановить / остановит].

'The most important thing is that there is no (political) force that would be able to stop that.'

[Беседа в Воронеже (2001)]

The semantic type of predicate in the main clause

Subjunctive relative clauses are most typical in the contexts with predicates such as нет, (не) существовать, (не) было.

Table 1 shows the results of the search for the construction «нет [from 1 to 8 words] который». I did not consider counterfactual clauses like (5) above, or real clauses like (2). The Corpus shows that the subjunctive is used in the majority of cases, such as (13), while the indicative marking is infrequent, but see (14). Relative clauses with modals such as мочь, можно were grouped separately, since these predicates often occur under the same conditions as the subjunctive (15); the two phenomena are thus not independent.

\begin{tabular}{|l|l|}
\hline subjunctive & $81 \%$ \\
\hline indicative: with modals мочь, можно/ other & $8 \% / 11 \%$ \\
\hline
\end{tabular}

TABLE 1: Relative clauses with the negative predicate нет (93 tokens in total) 
(13) Авторов, которые сегодня писали бы увлекательные книги для детей, Heт.

'Today, there are no authors who can/are able to write fascinating children's books.'

[Анна Ковалева. Елена Соломатина: «Для детей никто не пишет» (2002) // «Известия», 2002.09.10]

(14) В самом-самом начале это не так страшно, ещё нет плаценты, через которую вся бяка передаётся.

'At the very beginning this is not so bad, as there is yet no placenta through which all the infections are transferred.'

[Беременность: Планирование беременности (форум) (2005)]

(15) Hет и программного обеспечения, которое может быстро обрабатывать этот поток информации.

'There is no software that allows fast processing of all this information flow.'

[Александр Волков. Одеться с иголочки и без ниточки // «Знание сила», 10, 2003]

All sentences in the sample that use the indicative (not counting those the modals мочь, можно) have one thing in common: they contain generic statements, indicating that the situation denoted by the relative clause is usually true:

(16) Я Я говорю Анне < . . > что в La Perla нет совсем открытого сексуального вызова, который всегда отдаёт вульгарностью, но есть чувственная физиологичность.

'I'm telling Anna ... that La Perla underware is never obviously and crudely sexual, something which always exudes vulgarity, but that it possesses physiological sensuality.'

[Анна Карабаш. La perla, или мало ли что? (2002) // «Домовой», 2002.]

Compare:

(17) $\quad$ a. $\quad \checkmark$ Здесь нет вызова, который всегда отдает вульгарностью.

b. ?? Здесь нет вызова, который всегда отдавал бы вульгарностью.

c. $\checkmark \checkmark$ Здесь нет вызова, который отдавал бы вульгарностью.

The subjunctive is typical of those negative constructions with нет which denote specific rather than generic situations:

(18) Сегодня нетни одной ежедневной газеты, которая бы не была откровенным подручным мәра или губернатора.

'Today, there is no daily paper that would not be the mayor's or the gov- 
ernor's obvious mouthpiece.'

[Дмитрий Волков, Владимир Сунгоркин. Кухня управляемой демократии // «Отечественные записки», 2003]

(19) У моих детей в школе по-моему нет ни одного «любимого учителя» ... который заинтересовал бы детей своим предметом ...

'At school, my children have no favorite teacher I think ... a teacher who would get the children interested in the course.'

[Наши дети: Подростки (2004)]

In addition to the negated predicates, there are predicative words which signal the non-existence of the object, though they have no overt negative element: отсутствовать, отнимать, лишать, быть лишенным. These predicates may also take NPs which are relativised by a subjunctive clause:

(20) Взрослые и дети переживают все три этапа примерно одинаково с той лишь поправкой, что ребенок лишен взрослого опыта, на который мог бы опереться.

'Adults and children live through each of these three periods in the same way, the only difference being that a child does not have an adult's experience to rely upon.'

[Евгения Власова. Дети и смерть (2002) // «Домовой», 2002.08.04]

Subjunctive relative clauses are also typical with prepositional phrases with бeз 'without':

(21) Здоровые мужики пропадают в колониях годами без цели в жизни, которую могла бы им дать семья.

'Healthy, strong men spend years of their lives in penintentiaries. They lack purpose in life which they could find by starting a family.'

[Сергей Авдеев. Тюрьма и женитьба стали синонимами (2002) // «Известия», 2002.07.17]

Apart from the predicates of absence, subjunctive relative clauses are usually triggered by negative intensional predicates ${ }^{1}$. The isolation of this class of predicates seems to be important for the study of the Russian genitive of negation which is semantically close to the hypothetical subjunctive (see Borshchev et al. (2007); Kagan (2007)). According to E.V. Paducheva, the negative genitive of subject is typical of existential and perception verbs (Paducheva 1997), whereas the negative genitive of object is used with verbs of creation, perception, knowledge, possession and movement (Paducheva 2006). The negative counterparts of such verbs imply either the non-existence of the object or subject in question, or its visu-

[1] The properties of certain types of intensional verbs under negation were discussed in Kobozeva (1988). 
al absence. Compare, for instance, the following two examples (Paducheva 2005, 88):
a. Сомнений не возникло.
'No doubts arose.'
b. ' 'Сомнений не исчезло.
'No doubts faded away.'

A similar approach was adopted by Kagan (after Farkas (1985)) when referring to the notion of weak intensional verbs ("... verbs whose complement clause is not asserted to be true in a given set of accessible worlds but rather is related to world ranking" (Kagan 2007, 103)). According to Kagan, only weak as opposed to strong intensional verbs license the assignment of the Irrealis Genitive and allow the subjunctive mood. The subjunctive relativization of the subject is attested in the Corpus with the following predicates under negation: быть (было, бывает, будет), видно, возникать, выцвигаться, найтись, оказаться, оставаться, остаться, подходить, получаться, попасться, появиться, приниматься, принят, родиться, случиться, создан, состояться, срываться, существовать, хватать, являться.

. . . В последние же два десятилетия из наших судов не выдвинулся ни один судья, который приобрел бы всеобщую известность и симпатии в русском обществе ...

'In the last two decades, there has been no judge to step out of our legal system that would become famous and gain the sympathies of the public.' [Б. А. Кистяковский. В защиту права (1909)]

(24) Ещё не родился такой экономист, который бы считал, что другие делают всё правильно.

'There has been no economist who would admit that others do the right thing.'

[Сергей Минаев. Есть ли у вас план, мистер Греф? (2002) //

«Вечерняя Москва», 2002.04.11]

The subjunctive relativization of a direct object or, sometimes, of a more peripheral argument, occurs with the negated predicates видеть, вспоминать, встречать, вызывать, вырабатывать, выстроить, делать, довести до, допускать, достичь, задавать (вопросы), замечать, знать, инициировать, найти, обеспечить, обладать, обнаружить, объединены, открыть, подарить, позволять себе, получить, пользоваться (чем), помнить, построить, предпринимать, прекращать, привести, припомнить, продвинуть, произвести (действие), произнести, располагать, родить, сделать, сльшать, снабжать, содержать, сочинить, увидеть, употреблять, установить, хотеть. 
(25) И тут органы власти на местах достаточно неорганизованны, они не вырабатывают меры, которые могли бы снизить риски.

'And the local administration is not sufficiently organized, they are not developing the kind of measures that would minimize the risks.

[Екатерина Григорьева. Валентин Степанков: «Местные власти недооценивают угрозу терроризма» (2003) // «Известия», 2003.10.03]

(26) Премьер не допускает заметных ошибок, которые могли бы нанести ущерб репутации власти.

'The prime minister does not make mistakes that would do any harm to the reputation of the officials.'

[Алексей Макаркин. Черные метки для «белого воротничка Nr.1» (2003) // «Совершенно секретно», 2003.05.05]

(27) Иушла, не подарив ни комплимента, ни воспоминания, которыми можно было бы перед Нерлиным погордиться . . .

'And then she left, without offering her either a compliment or a memory to boast when she'd meet Nerlin.'

[Ольга Новикова. Мне страшно, или Третий роман // «Звезда», 2003]

Under negation, these predicates imply that their argument lacks the presupposition of existence:
a. Не родился экономист
$\Rightarrow$ there is (was) no economist (lit. the economist was not born)
b. Не подарила комплимента
$\Rightarrow$ there is (was) no compliment (lit. the compliment was not offered)

In the corpus, the only example of a subjunctive clause relativising an object which does not lack the presupposition of existence is a non-affirmative sentence (question):

(29) Надь, а ты не пользуешься никакими кремами, которые сушили бы эти прыщики . . . мне как-то от биотерма посоветовали, но я что-то не поверила ...

'Nadja, don't you use any cream that would dry out these pimples?.. Once I was advised to use the one made by Biotherm, but I didn't believe them for some reason.'

[Красота, здоровье, отдых: Косметика и парфюм (форум) (2004)]

As will be discussed below, an interrogative illocution often increases the acceptability of the subjunctive, cf.: 
(30) ?? Она не пользуется кремами, которые сушили бы прыщики. 'She does not use any creams that would dry out the pimples .'

The predicates listed above are not homogenous with regard to the "subjunctivebias". Some verbs are widely used with the subjunctive both used negatively and positively. For example, the predicates вспоминать, выбирать, дожидаться, найти / искать, нужен, обеспечивать, определять, открывать, построчть, представлять, принимать, сделать, снабжать, создавать, хотеть take a subjunctive relative clause irrespective of their polarity status.

(31) a. Он не ищет женщину, которая бы его любила.

b. Он ищет женщину, которая бы его любила.

'He is not / is looking for a woman who would love him.'

(32) a. Они не хотят музыки, которая заставляла бы их думать.

b. Они хотят музыку, которая заставляла бы их думать.

'They do not want / want the kind of music that would make them think.'

Other predicates, like видеть, замечать, сльшать, обладать, are hardly ever used with the subjunctive without negation.

(33) a. Я не вижу документов, которые могли бы подтвердить этот факт.

b. Я вижу документы, которые могут [* могли бы] подтвердить этот факт.

'I can see / I can see no documents that could confirm that.'

(34) a. Университет не обладает средствами, которые позволили бы ему приглашать западных профессоров.

b. Университет обладает средствами, которые позволяют [*позволили бы] ему приглашать западных профессоров.

'The university does not have/has enough funds to invite Western lecturers.'

This classification is a scale rather than a clear-cut division, since the ability of the verb to license the subjunctive can be increased by some additional factors like the modal нужно:

(35) Мне нужно увидеть документы, которые могли бы подтвердить этот факт.

'I need to see the documents that would confirm this.'

These factors will be discussed in detail below. Presently, we can claim that: 
(a) All predicates which may introduce subjunctive relative clauses outside negative contexts, may do so under negation as well (with the exception of internally negated predicates like лишен). In this paper, I will refer to these predicates as positive-negative subjunctive predicates.

Thus, the negative status of the main predicate is one of the strongest but not the only factor that influences the usage of the subjunctive. The second claim is that:

(b) There are predicates which license the subjunctive when they are negated, whereas their positive counterparts are hardly used with the subjunctive without some special conditions. I will refer to these predicates as negative-only subjunctive predicates.

What makes these predicates behave in a different way? The general tendency is that negative-only subjunctive predicates imply the existence of an NP when they are used positively:

a. Я вижу документы $\Rightarrow$ 'the documents exist'

b. Университет обладает средствами $\Rightarrow$ 'the resources exist'

On the contrary, positive-negative subjunctive predicates do not presuppose the existence of an NP:

(37) Он ищет женщину $\Rightarrow$ 'the woman he is looking for may exist or not'

(38) Они хотят музыку $\Rightarrow$ 'the music they want may exist or not'

Thus, the third claim is that:

(c) The negative-only subjunctive predicates are those whose positive counterparts imply the existence of an NP.

The restriction on the NPs which lack the presupposition of existence leads us to the second factor necessary for the felicity of the subjunctive relative clause: the head NP must be non-specific.

Referential status of the head noun

The constraint that the referent of the noun should not exist explains why definite and specific objects are not likely to become the heads of subjunctive relative clauses even under negation, cf. examples (39) and (40). In (39), the subjunctive relative clause is not felicitous, since the subject (женщина) is unique and real; in (40), the existence of the subject (женщина) is not implied (examples of E.V. Paducheva). 
(39) Не вижу женщину, которая стояла [*тояла бы] недалеко от выхода. 'I do not see the woman who stands next to the exit'

(40) Не вижу женщины, которая стояла бы недалеко от выхода. 'I don't see any woman standing next to the exit'

Subjunctive relative clauses under negation most often refer to a non-specific NP and thus tend to be restrictive.

Tense

The main clause of the sentences under negation is not restricted in terms of temporal reference.

PAST

(41) Говорят, не было ни одной отрасли знания, которой бы он не интересовался и которую бы он не изучал.

'They say, there was not a single branch of knowledge that he would not be interested in and would not investigate.'

[Георгий Орлов. Галерея масонских портретов (2003) // «Лебедь» (Бостон), 2003.07.28]

PRESENT

(42) Я не знаю таких примеров, которые подтверждали бы ваш тезис.

'I know of no examples that would support your point.'

[Борис Нисневич. ЕГЭ для Путина (2003) // «Калининградская правда», 2003.06.10]

FUTURE

(43) Убежден, что в Думе не будет одной фракции большинства, у которой было бы 226 голосов.

'I am convinced that there will not be a single majority party in the Duma that will have 226 seats.'

[Евгений Жеребенков. Кадры мешают все (2003) // «Итоги», 2003.03.25]

Russian and French

The comparison with French shows an important difference between the two languages. Unlike Russian, in French, indicative relative clauses are impossible with a negative predicate or under negation.

(44) Il n'y a pas aujourd'hui d'auteurs qui écrivent (SUBJ) des livres qui intéressent les enfants. 
'Today, there are no authors who can / are able to write fascinating children's books.'

(45) Je n'ai jamais commis d'actions dont j'aie (SUBJ) à avoir honte.

'I have never done things that would make me feel ashamed of myself.'

*Je n'ai jamais commis d'actions dont j'ai (IND) à avoir honte.

(46) L'enfant manque d'expériences sur lesquelles il puisse (SUBJ) s'appuyer.

'The child lacks experience he could rely upon.'

*L'enfant manque d'expériences sur lesquelles il peut (IND) s'appuyer.

\section{Truth value}

Thus, Russian relative clauses under negation, which imply the lack of presupposition of existence of the head noun, can be expressed both by the indicative and by the subjunctive, while French requires the usage of the subjunctive only.

Why do both languages license the subjunctive under negation? The fact can be connected to the well-known typological observation that there are languages which consistently mark negative events as unreal, because the negated event has never occurred in the real world. According to (Elliott 2000, 78) (after (Mithun 1995)), languages which mark a realis / irrealis distinction fall into two main types. Some languages consider the non-occurrence of an event as an actual occurrence in the real world: the event did not occur and these languages therefore mark negated events by the realis mood. Other languages mark negated events by the irrealis mood since the negative predicate denotes the event which did not occur in the real world. The languages which have no morphological realis / irrealis distinction, such as Russian and French, do not mark negative verbal forms by the irrealis mood, but, as we have seen, use other means to indicate that the negated situation is not real. French chooses the subjunctive since it interprets the properties of the negated situation as unreal, based on the fact that they do not exist in the real world. The properties of the negated situation are thus considered to be equal to a "genuine" counterfactual situation.

Russian is ambivalent: relative clauses under negation can be marked by the subjunctive or by indicative, if the head noun lacks the presupposition of existence. Why do relative clauses triggered by a non-specific NP license both the subjunctive and indicative?

I suggest the following explanation. If the head noun is indefinite, it denotes a class of objects rather than an individual object. The negation of such NPs does not necessarily imply that the situation, which is denoted by the relative clause, could not occur. The speaker cannot be as confident about the absence of a nonspecific object as he can when the object is specific, definite and individuated. In example (47a) below, the speaker can choose the indicative because the situation may occur in some possible world - generally speaking, authors who write good 
children's books may exist. On the other hand, the speaker is also free to choose the subjunctive, because the situation is unreal with regard to the particular case that he is speaking about (example (47b)).

(47) a. Нет авторов, которые пишут интересные книги для детей.

'There are no authors who can/are able to write interesting children's books'.

b. Нет авторов, которые писали бы интересные книги для детей.

'There are no authors who can/are able to write interesting children's books'.

\section{[3.2] Subjunctive relative clauses under positive polarity}

As was shown in the previous section, the presence of negation in the main clause is a strong factor which influences the usage of the subjunctive in relative clauses. However, the subjunctive is not used exclusively under the scope of negation. The availability of the subjunctive with positive predicates depends on the following factors:

(a) the semantic type of the predicate

(b) the referential status of the head noun

(c) the epistemic status of the relative clause

(d) the affirmative vs. interrogative status of the utterance

Semantic type of the predicate

The range of predicates that license the subjunctive in relative clauses without being negated (defined in the previous section as positive-negative subjunctive predicates) is more limited than those that license the subjunctive under negation.

The hypothetical subjunctive is often used in relative clauses introduced by a main clause containing an intensional verb or noun, a verb of creation, or a modal predicate such as необходим, нужен. All these verbs and nouns indicate either that the object or the event referred to by the head NP does not yet exist (48a), or that there is no reliable evidence confirming whether it exists or not, cf. (48b), (48c), (48d).

(48) a. Вячеслав Глазычев предложил создать так называемое «второе метро», которое имело бы не кольцевую структуру, а пересекало бы город поперек.

'Vyacheslav Glazychev suggested to create the so-called 'second subway' that would not be "circular" in structure but would cross the 
city in a straight line.'

[Генплан не поможет // РБК Daily, 2007.12.06]

b. Таким манипулированием изменить статус правительства / както попытаться / чтобы выбрать нормального человека / который бы отвечал за свои действия.

'... to change the position of the government through such manoeuvring / as to somehow try / to elect a reasonable person / who would feel the responsibility for what he does.'

[Беседа в Воронеже (2003)]

c. Ищу внебюджетную организацию, которая бы позволилане развалить профессиональный спорт и эти достижения.

'I am looking for a non-federal organization that would not allow the destruction of professional sport and its achievements.'

[Виктор Филиппов, Архангельск. 'Водник' приговорили к безденежью // Известия, 2007.12.24]

d. «Локо» необходима твердая рука, которая наконец направила бы команду в нужном направлении, сделала бы результаты и игру команды стабильными.

“ "Loco" needs a tough manager who would in the end steer the team in the right direction, who would make the team's results and performance more consistent/stable .'

[Артемий Бартков. Дотерпим // РБК Daily, 2007.12.05]

According to our data, the following predicates and verbal nouns occur with subjunctive relative clauses: агитировать, выбрать, выдвинуть, дожидаться, ждать, искать / найти, необходим, нужен, обеспечить, образовать, определить, организовать / организация, открывать (магазин), подготовить, построить / построение, представить, привлекать / привлечение, придумать, принимать, разработать / разработка, сделать, снабдить, создать/создание, формировать, формулировать.

Thus, the main factor which triggers the usage of the subjunctive with positive predicates is no commitment that the head noun exists. However, these predicates are not homogenous and allow the subjunctive to varying degrees. Some of them are compatible with the subjunctive without any additional conditions, whereas others need a special context supporting the possibility of the subjunctive:

(49) а. Мы ищем цель, к которой будет стремиться [ $\checkmark$ стремилось бы] все общество.

'We are looking for an objective that would interest the wider public.'

b. Мы представляем себе цель, к которой будет стремиться [??стремилось бы] все общество. 
'We may have in mind an objective that would interest the wider public.'

Various factors that increase the predicate's compatibility with the subjunctive will be discussed further below.

\section{Non-specific NPS}

The subjunctive is more likely to be used the less referential the nominal phrase is. This was shown by (Kagan 2007, 168):

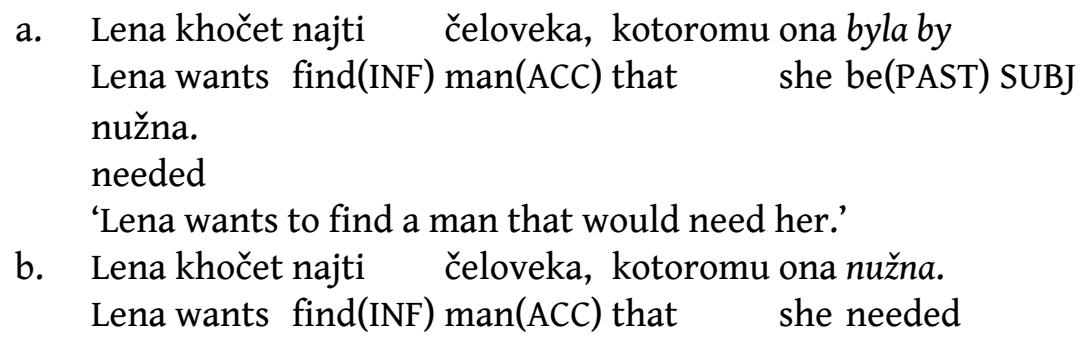

a. Lena khočet najti čeloveka, kotoromu ona byla by Lena wants find(INF) man(ACC) that she be(PAST) SUBJ nužna. needed 'Lena wants to find a man that would need her.'

b. Lena khočet najti čeloveka, kotoromu ona nužna. Lena wants find(INF) man(ACC) that she needed 'Lena wants to find a man that needs her / the man who needs her.'

Only (50b) can mean that Lena is looking for a particular man who, as she knows, needs her. Similar examples were discussed in (Dobrushina 2009, 293).

The correlation between the specificity of the arguments and the use of irrealis has been observed in different languages and has been discussed in the typological studies (Givón 1994, 302), (Chafe 1985, 362), (Plungian 2005, 138). The more specific the arguments of the predicate are, the less likely is the use of irrealis.

This is why subjunctive relative clauses are more typical of nominal phrases that are modified by the pronoun такой ('such'), whereas NPs modified by the pronoun mom ('that') more often head indicative relative clauses. An NP with такой usually refers to a class of objects and is thus more compatible with the irrealis mood form, while an NP with mom refers to a single object, even if it is not definite.

(51) Теперь главная моя задача - найти такого Савву Морозова или мадам фон Мекк, которые бы вложили деньги в мой проект.

'Now, my main problem is to find somebody like Savva Morozov or M-me von Mekk who would invest in my project.'

[Белла Езерская. Музыкальная история (2003) // «Вестник США», 2003.]

(52) Я найду ту, которая полюбит меня. Она должна быть молодой, умной, красивой, доброй, отзывчивой, верной.

'I will find the one who will love me. She must be young, clever, beautiful, 
kind, sympathetic, and faithful'.

[Владимир Шахиджанян. 1001 вопрос про ЭТО (NN 1-500) (1999)]

Subjunctive relative clauses licensed by intensional or modal predicates are always restrictive. Cf. a non-restrictive relative clause in (53) where only the indicative is possible:

Необходимо использовать инерцию падения тела, которое само выброcum [* выбросило бы] вас в защитную позицию.

'One has to use the momentum of a falling body that will make you adopt a defensive position.'

[Алексей Яшкин. Акробатика в каратэ (2004) // «Боевое искусство планеты», 2004.06.10]

However, there are some examples where hypothetical subjunctive relative clauses are used with definite NPs. Example (54) below can be interpreted hypothetically; and the subjunctive in the relative clause can be substituted by the future indicative:

(54) В таком случае / вам нужно пригласить сюда мою маму / которая очень много бы вам сказала $[\checkmark$ скажет].

'Then you should invite my mom to come here / she could tell you really a lot'.

[Беседа с Д. Арбениной, лидером группы «Ночные снайперы», «Школа злословия», канал «Культура» (2003)]

The subjunctive in (54) is possible because the situation which is denoted by the relative clause is highly improbable (the mother of the interviewee is unlikely to be invited to the talk-show). The strong factor which triggers the usage of the subjunctive is thus the epistemic status of the relative clause.

Epistemic status of the relative clause

The subjunctive in a relative clause with an intensional verb becomes more probable if the intensional verb is introduced by a modal matrix verb. Modal verbs often signal that the speaker is uncertain with regard to what is asserted. The subjunctive is more probable if the probability of a particular situation to happen is smaller. Table 2 on the following page shows the results of the search for different modal verbs with the verb найти in the corpus. ${ }^{2}$

The table shows that the subjunctive is more felicitous with those modifiers which imply a low probability of the existence of an object / situation:

[2] The idea for this search was suggested by Maria Kholodilova. 


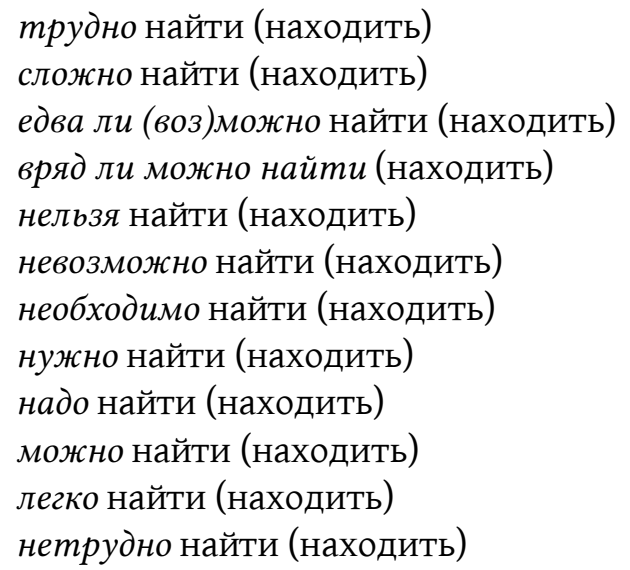

$\begin{array}{cc}\begin{array}{c}\text { SUBJUNCTIVE } \\ \text { relative clause } \\ \text { (number of ex.) }\end{array} & \begin{array}{c}\text { INDICATIVE } \\ \text { relative clause } \\ \text { (number of ex.) }\end{array} \\ 75 & 3 \\ 5 & 2 \\ 3 & 0 \\ 4 & 0 \\ 8 & 1 \\ 8 & 5 \\ 8 & 6 \\ 11 & 10 \\ 19 & 12 \\ 4 & 46 \\ 0 & 5 \\ 0 & 8\end{array}$

TABLE 2: Relative clauses with modals + найти

(55) Трудно найти такого еврея, который не захотел бы лечь в назначенный час в иерусалимскую землю, среди своих, на вечное хранение ... 'It is hard to find a Jew who would not like to be buried in the Jerusalem soil, to rest in peace amidst his own brethren.'

[Давид Маркиш. Стать Лютовым. Вольные фантазии из жизни писателя Исаака Бабеля // «Октябрь», 2001]

(56) Вместе с тем, вряд ли можно найти такое же количество судей, которые бы знали, каковы закономерности применения оговорки на практике.

'At the same time, it is hardly possible to find the same number of judges who would know how the provision is practically applied.' [«Арбитражный и гражданский процессы», 2003.06.23]

The speaker's high degree of confidence that the situation may take place would more likely be expressed by the indicative, as in (57), though the subjunctive is not ungrammatical either:

(57) Прежде всего потому, что всегда можно найти достойную, абсолютно честную работу, которая обеспечит [ $\checkmark$ обеспечила бы] достаток и тебе самому, и твоей семье.

'And first of all, because it is always possible to find a worthy and honest job that will guarantee you and your family a decent income.' [Смотрите, кто уехал (2002) // «Известия», 2002.12.24] 
The modal verbs необходимо, нужно, надо do not convey any estimate of the probability of the situation in the relative clause. There are thus equal chances that the subjunctive or indicative will be chosen.

(58) Надо разработать такую социальную систему, которая максимально защищала бы детей из малообеспеченных семей.

'We should create a social infrastructure that would support children coming from families with low income.'

[Ирина Мельникова. Школа выживания (2003) // «Итоги», 2003.02.11]

(59) Необходимо каждый раз находить эту щемящую ноту, которая бы пронзила зрителей.

'Again and again one has to find a melancholy pitch that would pierce the audience.'

[Анастасия Гулина. Слух к чужой боли (2003) // «Богатей» (Саратов), 2003.09.11]

The modal adjectives необходим and нужен may also trigger both subjunctive or indicative relative clauses. Table 2 shows the statistics for the subjunctive vs. indicative predicates in relatives clauses with these adjectives. According to these data, the indicative occurs more often:

$\begin{array}{lcc} & \begin{array}{c}\text { SUBJUNCTIVE } \\ \text { relative clause } \\ \text { (number of examples) }\end{array} & \begin{array}{c}\text { INDICATIVE } \\ \text { relative clause } \\ \text { (number of examples) }\end{array} \\ \text { необходим } X & 29 & 46 \\ \text { нужен } X & 28 & 53\end{array}$

TABLE 3: Relative clauses with modals необходим and нужен

Factors influencing the choice of the mood after these modal words are not always clear. It seems that there is a tendency to choose the indicative when describing concrete situations, cf. (60) and (62), whereas the subjunctive is more used to describe generic situations, as in (61) and (63):

(60) Юрист-теоретик тоже не сможет помочь, здесь необходим человек, который знает именно практическую сторону вопроса.

'A legal theoretician won't be able to help, either; here you need someone who knows the practical ins and outs of this problem.'

[Мария Демидова. Малому бизнесу пока невыгодно выходить из тени (2003)] 
(61) Для осуществления реставрации парка необходимы специалисты по ландшафтному дизайну и паркостроению, которые могли бы осуществить составление сметы стоимости восстановительных работ ...

'To reconstruct the park we need landscape and public park designers who would be able to evaluate the cost of the restoration works.'

[Мария Дробина. Основные направления реконструкции пейзажного парка-усадьбы Братцево (2003) // «Биология», 2003.07.01]

(62) Тут нужен директор, который будет действовать в жестко очерченных рамках.

'Here, we need a director who would work within a very clearly defined framework.'

[Алексей Жданов. Как управиться с менеджером // «Деловой квартал» (Екатеринбург), 2003]

(63) Нам нужны такие руководители, которые хотели бы развиваться как квалифицированные менеджеры ...

'We need business managers who would be willing to develop into highly qualified CEOs.'

[Алексей Жданов. Как управиться с менеджером // «Деловой квартал» (Екатеринбург), 2003]

Other predicates are compatible with the subjunctive almost exclusively in contexts which imply that the situation is improbable. For example, the verb npedставлять ('have in mind') is hardly used with the subjunctive without modifiers which emphasize that the situation is unlikely to occur, whereas искать does not need any support context:

(64) а. Мы ищем цель, к которой будет стремиться [ $\checkmark$ стремилось бы] все общество.

'We are looking for an objective that would motivate the general public.'

b. Мы представляем себе цель, к которой будет стремиться [??стремилось бы] все общество.

'We have in mind an objective that would motivate the general public.'

c. Трудно представить себе цель, к которой будет стремиться $[\checkmark$ стремилось бы] все общество.

'It is hard to think of an objective that would motivate the general public.' 
If the situation denoted by the relative clause is judged to be improbable, the clause may use the subjunctive even with negative-only subjunctive predicates. Compare example (65a) with (65b) and (65c):

(65) а. Университет обладает средствами, которые позволяют [*позволили бы] ему приглашать западных профессоров.

'The university has funds that allow it to invite professors from the West.'

b. Мало российских университетов обладают средствами, которые позволили бы им приглашать западных профессоров.

'There are not many Russian universities that have funds that allow them to invite professors from the West.'

c. Вряд ли этот университет обладает средствами, которые позволили бы ему приглашать западных профессоров.

'It is improbable that this university has funds that would allow it to invite professors from the West.'

\section{Questions}

The subjunctive is often possible in questions. The modal verb можно tends to introduce indicative relative clauses (see Table 2 on page 198). But in interrogative sentences, the subjunctive is used more often; (concerning the usage of the irrealis mood in questions in other languages see (Palmer 2001, 172-173)):

$\begin{array}{lcc} & \begin{array}{c}\text { subJunctive } \\ \text { relative clause } \\ \text { (number of ex.) }\end{array} & \begin{array}{c}\text { INDICATIVE } \\ \text { relative clause } \\ \text { (number of ex.) }\end{array} \\ \text { можно найти (находить) } & 4 & 46 \\ \text { можно ли найти (находить) ...? } & 7 & 1\end{array}$

TABLE 4: Relative clauses in interrogatives

(66) Можно ли найти еще одну отрасль научного знания, которая бы так прочно вошла в нашу жизнь?

'Is it possible to find another branch of scientific knowledge that would be so strongly integrated into our everyday life?'

[M. А. Степанова. Психология в образовании:психолого-педагогическое взаимодействие (2003) // «Вопросы психологии», 2003.07.22]

Another piece of evidence for the special correlation between the subjunctive and interrogatives comes from examples where a subjunctive relative clause is used with a definite NP: 
(67) Прочтя эти строчки, я пожал плечами: еще несколько месяцев тому назад кто бы мог себе представить Андрея, который бы говорил [ $\checkmark$ говорит] о южном небе и сладости бытия?

'I read these lines and shrugged: a few months ago, who on earth would have imagined Andrej speaking about the Southern sky and the delight of being?'

[Г. А. Газданов. Эвелина и ее друзья (1971)]

Questions license the usage of the subjunctive even if the verb is not intensional, cf. the examples below.

(68) a. - Скажи, тебе приходилось влюбляться в женщину, которая была бы старше тебя?

'Tell me, have you ever been in love with a woman who is older than you?'

[Коллекция анекдотов (1970-2000)]

b. *Мне приходилось влюбляться в женщину, которая была бы старше меня.

'I have been in love with women older than me before.'

(69) a. Есть ли у него родня, есть ли хоть на свете человек, который бы искренне, от души пожалел его?

'Does he have any relatives, a single soul who would be sorry for him in a sincere and hearty way?'

[Владимир Тендряков. Тройка, семерка, туз (1961)]

b. ??У него есть родня, есть человек, который бы искренне, от души пожалел его.

'He has relatives, there is someone who would truly feel sorry for him, from the bottom of his heart.'

Tense and aspect

Unlike subjunctive relative clauses under negation, which often have a past or present reference, the main clause of positive sentences typically refers to the future or has a generic reference. This difference between negative and positive clauses can be explained by their semantics. Negative clauses, as was shown above, are inherently unreal, since they denote an event which does not exist in the real world. Positive clauses can always be interpreted as unreal in the future, and, with a very restricted set of predicates, in the past and present. Compare (70a) and (70b), which do not imply that the woman does in fact exist, with (70c) where the verb is perfective and it is implied that the woman is found. The clause is thus real and the subjunctive is not allowed: 
(70) a. Хочу найти / ищу женщину, которая пустила бы меня переночевать.

'I want to find a woman who would let me in for a night'.

b. я искал женщину, которая пустила бы меня переночевать.

'I was looking for a woman who would let me in for a night'.

c. * Я нашел женщину, которая пустила бы меня переночевать.

'I found a woman who would let me in for a night'.

Russian and French

In French, hypothetical relative clauses may also optionally use subjunctive marking. The choice of the verb form depends mainly on how certain the speaker is about the eventual truth (or not) of the event.

(71) Ils ont prevu de créer un centre qui réunisse (SUBJ) / réunira (FUT) les caucasologues.

'They planned to create a department that would bring together specialists in the field of Caucasian studies.'

(72) Votre role c'est d'organiser un jeu qui intéresse (SUBJ) / intéressera (FUT) les enfants.

'You mission is to launch a game the children would be interested to play.'

(73) Il faut mettre au point un systeme qui protège (SUBJ) / protégera (FUT) les enfants de familles pauvres.

'It is necessary to come up with an infrastructure that would protect the children coming from families with low income.'

If the sentence denotes the situation which is higly unlikey to occur, the subjunctive is preferred:

(74) Il est difficile à un petit pays d'entretenir une armée qui puisse (SUBJ) / *IND faire face à l'ennemi.

A small country can hardly keep an army that would be able to withstand the enemy.

The subjunctive is used when the relativized object is non-specific. In (75a), the interpretation of the sentence depends on the form of the predicate: the indicative would mean that the coach wants to take some particular player, while the subjunctive implies that the player is as yet unknown ${ }^{3}$. Example (75b) does not allow the usage of the subjunctive because the NP is definite and the relative clause is non-restrictive.

[3] cf. "In Italian, and in other Romance languages, when the relative clause displays subjunctive marking $\ldots$, it forces the non-specific / attributive reading of the indefinite expression" (Panzeri 2004). 
(75) a. L'entraîneur veut engager un joueur qui élèvera (FUT $\Rightarrow$ SPECIFIC) / élève (SUBJ $\Rightarrow$ NON-SPECIFIC) le niveau de l'équipe.

'The coach wants to enroll a new player who will take the team to a higher level.'

b. L'entraîneur veut engager Petrov, qui élèvera (FUT) le niveau de l'équipe.

'The coach wants to enroll Petrov who will take the whole team to a higher level.'

Truth value

From the logical-semantic point of view, hypothetical relative clauses denote situations that may happen in the future and thus cannot be characterized as true or false in the present.

(76) Потому что здесь нужны законы, которые бы наказали его за дискриминацию на работе.

'Because here we need a legislation that would punish him for discriminatory behavior at work.'

[М. Ганапольский, Е. Лахова. Беседа М. Ганапольского с Е. Лаховой в прямом эфире «Эха Москвы» (2003)]

$\Rightarrow$ It may be true or false that законы накажут его за дискриминацию на работе.

\section{[3.3] Summary}

To sum up, the following factors contribute to the possibility to use the subjunctive in Russian hypothetical relative clauses. The main factor is that the situation expressed by the relative clause is neither true nor false, since there is a lack of knowledge about its truth value. This usually happens if

- The predicate of the main clause is negative

- The predicate of the main clause is intensional (if the sentence is affirmative)

- The head noun is non-specific

- The predicate of the main clause is introduced by a modal, especially a modal marking low epistemic status

- The sentence is a question; interrogative modality licences the usage of subjunctive relative clauses even with non-intensional verbs and definite NPs.

[4] SUBJUNCTIVE IN THE COUNTERFACTUAL RELATIVE CLAUSES

The usage of the subjunctive in relative clauses can be motivated by the counterfactual semantics of the situation. In this case, the subjunctive refers to an event 
which did not and will never occur, even though the speaker considers it as an alternative to the one which had really occurred. The truth value is definitely negative, and the subjunctive cannot be substituted by the indicative.

(77) С этим наставлением, которое спасло бы [* ${ }^{*}$ спасло] множество жизней в голодные годы, будь оно услышано, Дюма покинул Россию.

'After delivering this warning (that could have saved lots of lives during the years of the famine had it been taken into consideration), Dumas left Russia.'

[Рецепты национальных кухонь: Франция (2000-2005)]

$\Rightarrow$ It is false that это наставление спасло множество жизней в голодные годы.

(78) Во время обысков в их квартирах изъяли арсенал, которого хватило бы, чтобы вооружить пехотное отделение.

'When their flat was searched, stocks of weapons were found that would be enough to equip an infantry squad.'

[Ляна Шарова. Трассовики (2003) // «Ежедневные новости» (Владивосток), 2003.01.17]

$\Rightarrow$ It is false that арсенала хватило, чтобы вооружить пехотное отделение.

These contexts perfectly correspond to the typical conditional counterfactual usage of $\sigma b l$ in conditional clauses:

(79) Если бы это наставление было услышано, оно спасло бы множество жизней.

'Had they paid heed to his admonitions, many lives would have been saved.'

(80) Если бы арсенал не изъяли, его бы хватило, чтобы вооружить пехотное отделение.

'If the stocks of weapons had not be found and confiscated, the amount discovered would have been enough to arm an infantry squad.'

The predicate of the main clause is not necessarily intensional, so that the head noun is not necessarily presupposed not to exist. For example, the head noun in (81) denotes a definite group of people which is specific.

(81) Вот вам 32 миллиона электората / которые могли бы быть наши. 'Here you go, 32 million electors that could have belonged to us.' [Заседание клуба «Новые правые» (2004)]

Thus, counterfactual subjunctive relative clauses can also be non-restrictive:

(82) Жаль, нет уже В.В. Кожинова, с которымможно было быздесь поговорить. 
'It's a pity there is no V.V. Kozhinov with whom one could have a talk here.'

[Сергей Есин. Выбранные места из дневника 2001 года (2003) // «Наш современник», 2003.06.15]

To sum up, counterfactual clauses are free of all restrictions which were found for hypothetical relative clauses:

- They are not confined to intensional predicates

- They are not restricted to non-specific NPs

- They are not sensitive to polarity (i.e. they are used in both positive and negative utterances, and in interrogatives).

\section{[5] CONCLUSION}

Table 5 on the facing page provides a comparison of the three types of subjunctive relative clauses which were studied in the present paper. What is labelled the REAL (PRAGMATIC) subjunctive is almost synonymous with the indicative and can always be changed into an indicative form; it has no restrictions with regard to the type of the main predicate and the referential status of the head noun. Normally, it is used in dialogues and often has $1^{\text {st }}$ person reference.

(83) Вот вино, которое я хотела бы $[\checkmark$ хочу] / предложила бы $[\checkmark$ предлагаю] попробовать.

'Here is the wine that I would like you to taste.'

The next group, the HYPотнетіCAL subjunctive can be changed into indicative and describes a situation which has no truth value, since the speaker is not in a position to evaluate its truth. The main clause typically contains a negation and/or an intensional verb and the head noun is often low on the specificity scale.

(84) Мне нужно найти вино, которое стоило бы больше ста долларов за бутылку.

'I need to find a wine that would cost more than a 100 dollars per bottle.

However, the restriction regarding intensional verbs and non-specific NPs may be ignored if the sentence is interrogative or negative:

(85) a. Когда-нибудь я попробую вино, которое стоит [*стоило бы] больше 100 долларов.

'One day I will drink wine that costs over a 100 dollars.' 
b. Ты когда-нибудь пробовала вино, которое стоило бы больше 100 долларов?

'Have you ever had wine that would cost over a 100 dollars?'

c. Я никогда не пробовала вина, которое стоило бы больше 100 долларов.

'I never drank wine that would cost over a 100 dollars.'

Hypothetical clauses are fluctuating not only in that they allow both the subjunctive and indicative in Russian, but also in that Russian and French interpret hypothetical clauses differently since French has an obligatory subjunctive in relative clauses under negation.

Finally, COUNTERFACTUAL subjunctive relative clauses describe a situation which will never occur. These sentences lack all restrictions typical for hypothetical clauses and subjunctive clauses under negation: they can be headed by specific NPs and are not confined to intensional verbs.

\begin{tabular}{|c|c|c|c|c|}
\hline & \multirow[t]{2}{*}{ real subj. clauses } & \multicolumn{2}{|c|}{ hypothetical subj. clauses } & \multirow{2}{*}{$\begin{array}{l}\text { counterfactual } \\
\text { subj. clauses }\end{array}$} \\
\hline & & $\begin{array}{l}\text { subj. under neg. } \\
\text { predicate }\end{array}$ & $\begin{array}{l}\text { subj. under pos. } \\
\text { predicate }\end{array}$ & \\
\hline $\begin{array}{l}\text { the subjunctive } \\
\text { can be substituted } \\
\text { by the indicative }\end{array}$ & yes & $\begin{array}{l}\text { yes in Russian } \\
\text { no in French }\end{array}$ & yes & no \\
\hline truth value & true & \multicolumn{2}{|c|}{ not established } & false \\
\hline $\begin{array}{l}\text { predicates in the } \\
\text { main clause must } \\
\text { be intensional } \\
\text { verbs }\end{array}$ & no & \multicolumn{2}{|c|}{ yes } & no \\
\hline $\begin{array}{l}\text { the head noun has } \\
\text { to be low on the } \\
\text { specificity scale }\end{array}$ & no & \multicolumn{2}{|c|}{ yes } & no \\
\hline $\begin{array}{l}\text { typical tense } \\
\text { marking in the } \\
\text { main clause }\end{array}$ & pres & past / pres / fut & pres / fut & past / pres \\
\hline
\end{tabular}

TABLE 5: Real, hypothetical, counterfactual

The difference between the "genuine" counterfactual clauses, on the one hand, and the hypothetical subjunctive clauses and subjunctive clauses under negation, on the other, can be explained by the semantics of the Russian subjunctive. In Russian, the subjunctive is used to mark situations which are unlikely to come true. The "more unreal" the situation is judged by the speaker, the higher is the probability of subjunctive marking. Counterfactual situations meet this condition, since they are unlikely to occur; and thus they are always marked by the subjunctive. Hypothetical clauses, marked by the subjunctive, demand some ad- 
ditional conditions which increase their "irreality": negative polarity, low referential status of the NP, no existential commitment contributed by the verb of the main clause, modal verbs of low probability, and interrogative modality. The results of the present paper fit nicely with typological studies on this topic. According to Plungian, there are three semantic components which can influence the speaker's choice with regard to the marking of reality status:

- 'having taken place'

- 'being certain'

- 'being specific'

"When all these components agree, irreal marking is highly probable or even obligatory" (Plungian 2005, 138). As has been shown, the possibility of using the subjunctive in hypothetical relative clauses should be described by means of a scale rather than in terms of a set of cases / contexts. This and similar linguistic phenomena represent a perfect object for corpus-based studies, since corpus data allow us to calculate frequencies.

\section{AC KNOWLEDGMENTS}

My discussions with Elena Paducheva have greatly improved the paper. I am also grateful to Maria Kholodilova, Michael Daniel, Barbara Partee, Atle Grønn, Irena Marijanovic, Irina Kobozeva, and to the participants of the conference "Russian in contrast" (Oslo, September 17-19, 2009) as well as Arto Mustajoki's workshop at Helsinki University (March 11, 2009) and to the members of the working group "A New Corpus-Based Grammar of Russian" (Moscow).

Financial support for this research came in part from the Russian Foundation for the Humanities (grant No. 10-04-00256a) and the Science Foundation of the State University Higher School of Economics (grant No. 10-01-0131).

\section{REFERENCES}

Apresyan, Ju.D. 1995. Performativy v grammatike i v slovare. In Integral'noe opisanie jazyka i sistemnaja leksikografija, 199-219. Moskva: Škola «Jazyki russkoj kul'tury».

Bondarko, A.V., E.I. Beljaeva, L.A. Birjulin et al. 1990. Teorija funkcional'noj grammatiki. Temporal'nost'. Modal'nost'. Leningrad: Nauka.

Borshchev, V., E. Paducheva, B. Partee, Y. Testelets \& I. Yanovich. 2007. Russian Genitives, Non-Referentiality, and the Property-Type Hypothesis. In A. Antonenko et al. (eds.), Formal Approaches to Slavic Linguistics: The Stony Brook Meeting 2007 (FASL 16), Ann Arbor: Michigan Slavic Publishers. 
Chafe, W. 1985. The realis-irrealis distinction in Caddo, the Northern Iroquoian languages, and English. In J. Bybee \& S. Fleischman (eds.), Modality in grammar and discourse, John Benjamins Publishing Company.

Dobrushina, N.R. 2009. Semantika častic by i b. In K.L. Kiseleva, V.A. Plungian, E.V. Rakhilina \& S.G. Tatevosov (eds.), Korpusnye issledovanija po russkoj grammatike, 283-313. Moskva: Probel.

Elliott, J.R. 2000. Realis and irrealis: Forms and concepts of the grammaticalisation of reality. Linguistic typology 4(1). 55-90.

Farkas, D. 1985. Intensional Descriptions and the Romance Subjunctive Mood. New York: Garland Publishing.

Givón, T. 1994. Irrealis and the subjunctive. Studies in Language 18(2). 265-337.

Kagan, O. 2007. On the Semantics of Structural Case: Hebrew University: Ph.D dissertation.

Kampers-Mahne, B. 1991. L'opposition subjonctif/indicatif dans les relatives: University of Groningen: Ph.D dissertation.

Kobozeva, I.M. 1988. Otricanie v predloženijakh s predikatami propozicional'noj ustanovki. In Logičeskij analiz jazyka. Znanie i mnenie, 82-98. Nauka: Nauka.

Mithun, M. 1995. On the relativity of irreality. In J. Bybee \& S. Fleischman (eds.), Modality in grammar and discourse, John Benjamins Publishing Company.

Nikunlassi, A. 2008. Primestoimenno-otnositel'nye konstrukcii v sovremennom russkom jazyke (Slavica Helsingiensia 33). Helsinki University Press.

Paducheva, E.V. 1997. Roditel'nyj sub"ekta v otricatel'nom predloženii: sintaksis ili semantika? Voprosy jazykoznanija 2. 101-116.

Paducheva, E.V. 2005. Ešče raz o genitive sub"ekta pri otricanii. Voprosy jazykoznanija 5. 84-99.

Paducheva, E.V. 2006. Genitiv dopolnenija v otricatel'nom predloženii. Voprosy jazykoznanija 6. 21-43.

Palmer, F.R. 2001. Mood and Modality. Cambridge Textbooks in Linguistics. Cambridge 2nd edn.

Panzeri, F. 2004. Subjunctive Relative Clauses. In P. Denis, E. McCready, A. Palmer \& B. Reese (eds.), Proceedings of the 2004 Texas Linguistics Society Conference: Issues at the Semantics-Pragmatics Interface, Cascadilla Proceedings Project, Somerville, MA, USA. 
Plungian, V. 2005. Irrealis and modality in Russian and in typological perspective. In B. Hansen \& P. Karlik (eds.), Modality in Slavonic languages, 135-146. Munich: Verlag Otto Sagner.

Švedova, N.Ju. et al. 1980a. Russkaja grammatika, vol. I. Moskva: Nauka.

Švedova, N.Ju. et al. 1980b. Russkaja grammatika, vol. II. Moskva: Nauka.

CONTACT INFORMATION

Nina Dobrushina

State University Higher School of Economics

Department of language and literature

Miasnitskaya 20, Moscow, 101000

Russia

nina.dobrushina@gmail.com 